* Doutor e Mestre em Direito pela Universidade Federal do Paraná - UFPR. Professor Adjunto da Universidade Federal de Mato Grosso do Sul - UFMS. Líder do Núcleo de Pesquisa em Estado e Política-NUPEPOL, coordenador do Projeto de Pesquisa Observatório Constitucional

** Acadêmica do Curso de Direito da Universidade Federal de Mato Grosso do Sul - UFMS. Participante do Programa de Iniciação Científica Voluntária PIVIC no Projeto Observatório Constitucional e membro do Núcleo de Pesquisa em Estado e Política - NUPEPOL.

\section{OS 30 ANOS DAS CONSTITUIÇÕES ESTADUAIS NO BRASIL E OS DIREITOS FUNDAMENTAIS ESTADUAIS.}

\section{YEARS OF STATE CONSTITUTIONS IN BRAZIL AND THE STATE FUNDAMENTAL RIGHTS.}

\section{Luís Fernando Sgarbossa* Laura Cabrelli Bittencourt **}

Como citar: SGARBOSSA, Luís Fernando; BITTENCOURT, Laura Carelli. OS 30ANOS DAS CONSTITUIÇÕES ESTADUAIS NO BRASIL E OS DIREITOS FUNDAMENTAIS ESTADUAIS. Revista do Instituto de Direito Constitucional e Cidadania IDCC, Londrina, v. 4, n. 1, p 90-116, ago, 2019. ISSN: 2596-0075. https://doi.org/10.48159/revistadoidcc.v4n1.sgarbossa.bittencourt

Resumo: A temática do constitucionalismo estadual ou subnacional é relevante e, no entanto, ainda pouco estudada no Brasil. Diversos aspectos relativos ao constitucionalismo estadual pátrio são carentes de estudo, tal como o dos direitos fundamentais estaduais, objeto do presente estudo. $\mathrm{O}$ artigo constitui resultado parcial de pesquisa básica quanto à natureza $\mathrm{e}$ quantitativa/qualitativa quanto à abordagem, além de documental, de levantamento e bibliográfica, quanto aos procedimentos, além de lançar mão dos métodos estrutural-comparativo, técnicocomparativo e descritivo-comparativo. Após breve introdução, o trabalho traça um panorama comparativo das constituições estaduais brasileiras quanto a diversos aspectos, como extensão, conteúdo e estabilidade das cartas constitucionais subnacionais brasileiras. Após, delineia aspectos gerais relativos ao pluralismo constitucional brasileiro, entendido como a situação de covigência de ordens constitucionais geral e parciais, no que diz respeito aos direitos e garantias fundamentais, evidenciando a presença de direitos e garantias estaduais para além dos federais. Por fim analisa direitos fundamentais estaduais em espécie e questões conexas, notadamente a cláusula de abertura ou reenvio existente em diversas constituições estaduais, que conecta a ordem constitucional estadual, federal e, eventualmente, as ordens jurídicas supranacionais; examina a temática dos direitos fundamentais estaduais total ou parcialmente coincidentes com direitos análogos federais e, finalmente, examina a temática dos direitos fundamentais estaduais autônomos ou específicos, assim entendidos como os não coincidentes, total ou parcialmente, com os direitos fundamentais previstos na ordem constitucional 
federal.

Abstract: State constitutionalism is a relevant theme and, however, still little studied in Brazil. Several issues related to the state constitutionalism claim for studies, such as the state fundamental rights, object of the present paper. The article is a partial result of basic research on the nature and quantitative / qualitative approach, as well as documentary, survey and bibliographic, on procedures, besides using the structural-comparative, technical-comparative and descriptive-comparative methods. After a brief introduction, the paper provides a comparative overview of the Brazilian state constitutions in several aspects, such as the extension, content and stability of these charters. After, it outlines general aspects related to Brazilian constitutional pluralism, understood as the situation of coexistence of general and partial constitutional orders, with respect to fundamental rights and guarantees, evidencing the presence of state rights and guarantees beyond the federal ones. Finally, it analyzes some of the existing state fundamental rights and related issues, notably the opening clause existing in various state constitutions, which connects the state and the federal constitutional orders and, eventually, also the supranational legal order; examines the theme of state fundamental rights wholly or partially coincident with analogous federal rights, and finally examines the theme of autonomous or specific state fundamental rights, thus understood as those that do not fully or partially coincide with the fundamental rights provided for in the federal constitutional order

Palavras-chave: Federalismo; Constituições Estaduais; Constitucionalismo subnacional; Brasil; Análise estruturalcomparativa.

Key-words: Federalism; State Constitutions; Subnational constitutionalism; Structural-comparative analysis. 


\section{INTRODUÇÃO. ${ }^{1}$}

Em 2019 a maioria das Constituições dos Estados que atualmente integram a República Federativa do Brasil completam 30 anos, revelando-se a ocasião propícia para a publicização de resultados de pesquisas levadas a cabo tendo por objeto do pluralismo constitucional brasileiro e o Direito Constitucional subnacional pátrio.

O Estado brasileiro adotou a forma federativa de Estado com a proclamação da república, dando conformação jurídica à mesma por meio da Constituição de 1891 e mantendo tal forma de Estado desde então. Como decorrência da opção constituinte federalista, as antigas províncias, dali em diante Estados-membros, viram-se imbuídos de poderes constituintes derivados decorrentes, em virtude dos quais poderiam adotar suas próprias constituições e exercer as prerrogativas inerentes à autonomia, nos âmbitos da auto-organização, autolegislação e autogoverno.

O poder constituinte derivado decorrente, originalmente estabelecido no art. 63 da primeira carta republicana brasileira, foi previsto em todas as constituições sucessivas, a saber, na de 1934 (art. 7, I), 1937 (art. 21, I), 1946 (art. 18), 1967/1969 (art. 13) e, finalmente, no art. 25 da Constituição brasileira vigente, segundo o qual "os Estados organizam-se e regem-se pelas Constituições e leis que adotarem, observados os princípios desta Constituição".

Desde o começo da república, por conseguinte, manifesta-se o constitucionalismo estadual brasileiro e, consequentemente, o Direito Constitucional Estadual, tendo diversos Estados tido diferentes cartas constitucionais ao longo do tempo, de acordo com as modificações políticas, jurídicas e territoriais.

Por outro lado, é sabido que o federalismo brasileiro ostenta traços singulares. Apesar da clara inspiração do Direito Constitucional brasileiro no modelo norte-americano, que se revela na adoção de um conjunto de instituições em bloco (presidencialismo, federalismo, republicanismo, tripartição dos poderes, controle judicial de constitucionalidade), embora com importantes modificações, o tipo de federação entre nós estabelecido é bastante diverso do estadunidense, notadamente em termos de centralização (BONAVIDES, 2009).

A despeito da adoção, pelo texto constitucional, do princípio segundo o qual todas as competências não vedadas pela Constituição cabem aos Estados (art. $25 \S 1^{\circ}$ ) (SILVA, 2011), claramente inspirada na $X$ Emenda (1791) à Constituição dos EUA de $1787^{2}$, na prática a Constituição Federal reserva grande número de competências à União, deixando pouco âmbito

\footnotetext{
$1 \mathrm{O}$ presente estudo é elaborado a partir dos resultados parciais de pesquisa de levantamento de dados e bibliografia realizada no âmbito do Projeto "Observatório Constitucional: Direito Constitucional Comparado Interno e Externo", desenvolvido pelo Núcleo de Pesquisa em Estado e Política - NUPEPOL, na Universidade Federal de Mato Grosso do Sul - UFMS, Campus de Três Lagoas, coordenado pelo co-autor e do qual é membro a co-autora. O levantamento foi realizado por uma equipe de pesquisadores voluntários e bolsistas de iniciação científica durante o primeiro semestre do ano de 2019. Registra-se o agradecimento aos pesquisadores voluntários e bolsistas participantes da pesquisa, em particular aos bolsistas de iniciação científica Isabelle Caroline Silva, pela revisão parcial do texto, e o bolsista Guilherme Augusto Faria Valente, pelo auxílio prestado no levantamento bibliográfico.
}

2 "The powers not delegated to the United States by the Constitution, nor prohibited by it to the States, are reserved to the States respectively, or to the people." 
remanescente para os Estados (veja-se, a título de exemplo, o enorme rol de matérias de competência legislativa privativa da União no art. 22 da Constituição Federal vigente). ${ }^{3}$

Além disso, grande parte da organização dos Estados (e municípios) já é preestabelecida pela própria Constituição Federal, diversamente do que ocorre nos EUA, cuja carta fundamental regula essencialmente os poderes da União (arts. $1^{\circ}$ a $3^{\circ}$ ), e não os dos Estados. Trata-se das denominadas normas de pré-ordenação institucional (LEONCY, 2007).

Assim, exemplificativamente, a Constituição Federal vigente predetermina o unicameralismo em nível do legislativo estadual e o número de deputados Estaduais (art. 27), a duração do mandato e o regime jurídico básico dos parlamentares estaduais (art. $27 \S 1^{\circ}$ ) e os traços fundamentais do executivo estadual (art. 28), entre outros aspectos da organização das unidades subnacionais, o que limita a autonomia dos Estados (e municípios), além de impor grau razoavelmente elevado de homogeneidade entre os entes da federação.

Além desses dois fatores, é sabido que a jurisprudência do Supremo Tribunal Federal, com recurso ao princípio da simetria entre união e demais unidades da federação, tem historicamente anulado inúmeras tentativas de inovação local, impondo observância rígida do modelo federal pelos Estados, de modo não raro considerado exagerado, por esvaziar em grande medida a autonomia dos entes federativos. ${ }^{4}$

Registre-se, ainda, que o STF consagrou em sua jurisprudência predominante entendimento no sentido de impingir de maneira marcante a Constituição Federal como paradigma das constituições estaduais, por meio do conceito de normas constitucionais de reprodução obrigatória, assim entendidas como aquelas cuja repetição pelo constituinte estadual considera-se imposta pela Constituição Federal (LEONCY, 2007).

Por fim (mas não menos importante), resta o fenômeno das normas constitucionais de imitação, assim entendidas como aquelas normas constitucionais estaduais que correspondem a cópias de normas constitucionais federais (recepção material ou reenvio material) realizadas espontaneamente pelo legislador constituinte estadual (LEONCY, 2007).

Esse conjunto de fatores, associado a uma história de centralização do poder político, fazem com que o federalismo brasileiro distinga-se bastante do modelo estrangeiro que lhe serviu de paradigma, com grau muito superior de descentralização, como é sabido. ${ }^{5}$

A despeito de tais diferenças, que não devem ser desconsideradas ao se examinar comparativamente sistemas federais diversos, não parece correto imaginar, no entanto, que o

3 O presente estudo é elaborado a partir dos resultados parciais de pesquisa realizada com fomento da Universidade Federal de Mato Grosso do Sul - UFMS no âmbito do Programa Voluntário de Iniciação Científica - PIVIC (Edital UFMS PROPP n. 007 de 22.01.2019). Integra o Projeto "Observatório Constitucional: Direito Constitucional Comparado Interno e Externo", desenvolvido pelo Núcleo de Pesquisa em Estado e Política - NUPEPOL, na Universidade Federal de Mato Grosso do Sul - UFMS, Campus de Três Lagoas, coordenado pelo co-autor e do qual é membro a co-autora. O levantamento foi realizado por uma equipe de pesquisadores voluntários e bolsistas de iniciação científica durante o primeiro semestre do ano de 2019

4 Entre inúmeras decisões judiciais passíveis de menção, consultem-se as Representações ns. 93 e 94, ambas de 1947; as ADIs 508/MG, 699/MG, 409/RS, ADI/MC 347-0, ADI 486, ADI 429, ADIs 5646 e 5647 e RE n. 199.293-0.

5 Outro fator digno de nota é a influência de institutos oriundos do Direito Constitucional europeu continental, tais como o federalismo cooperativo e o controle abstrato de constitucionalidade, ambos dotados de efeitos centralizadores. Quanto ao último, é imperativa a consulta do estudo de TOMIO, ROBL FILHO e KANAYAMA, publicado em 2015 (vide referências). 
constitucionalismo subnacional ${ }^{6}$ brasileiro não possua qualquer relevância ou interesse, embora menor do que em sistemas menos centralizadores, devido à menor margem de liberdade de conformação das instituições locais.

Nessa esteira, convém examinar um dos temas mais relevantes do constitucionalismo subnacional brasileiro, frequentemente ignorado, a saber, o dos direitos fundamentais estaduais. Antes disso, porém, faz-se necessário traçar um panorama comparativo mínimo do constitucionalismo estadual brasileiro.

\section{PANORAMA COMPARATIVO DO CONSTITUCIONALISMO ESTADUAL BRASILEIRO}

Considerando-se o prazo de um ano a contar da promulgação da Constituição da República Federativa do Brasil para que as assembleias legislativas, investidas em poderes constituintes, elaborassem as constituições de seus respectivos Estados, estabelecido pelo art. 11 do Ato das Disposições Constitucionais Transitórias, constata-se que a maioria das constituições estaduais brasileiras foram promulgadas em 5 de outubro de 1989, ou antes dessa data.

Assim, foram promulgadas em 05.10.1989 as Constituições dos Estados de Alagoas, Amazonas, Bahia, Ceará, Espírito Santo, Goiás, Maranhão, Mato Grosso, Mato Grosso do Sul, Pará, Paraíba, Paraná, Pernambuco, Piauí, Rio de Janeiro, Santa Catarina, São Paulo, Sergipe e Tocantins (19 no total).

Algumas constituições estaduais foram promulgadas anteriormente a 05.10.1989 - 5, no total: Acre (03.10.1989), Minas Gerais (21.09.1989), Rio Grande do Norte e Rio Grande do Sul (03.10.1989), além de Rondônia (28.09.1989) -, ou posteriormente a tal data - 3 no total: Amapá (20.12.1991), Roraima (31.12.1991) e Distrito Federal (08.06.1993).

As constituições estaduais vigentes no Brasil completam, portanto, em 2019, 30 anos de vigência, em sua maioria, algumas completando duas 28 anos e a Lei Orgânica do Distrito Federal 26 anos.

Tais informações serão relevantes especialmente ao se analisar a frequência da manifestação do poder constituinte derivado decorrente reformador, que se traduzirá especialmente no número de emendas às constituições estaduais aprovadas durante tal lapso temporal, o que se passa brevemente a analisar.

\subsection{EMENDAS À CONSTITUIÇÃO: ANÁLISE QUANTITATIVA}

Todas as Constituições estaduais analisadas prevêem mecanismos de reforma, evidentemente, expressão daquela subespécie que poderia ser denominada doutrinariamente de poder constituinte derivado decorrente reformador (ou seja, o poder dos Estados membros e do

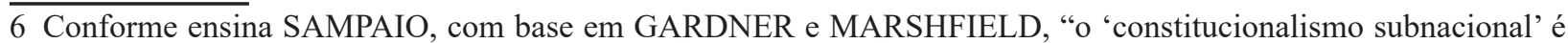
definido como uma ideologia e um conjunto de normas constitucionais que promovem os direitos fundamentais e a separação dos poderes nas unidades político-territoriais que se situam, sobretudo, imediatamente abaixo do governo nacional". (2019, p. 185). 
Distrito Federal reformarem suas constituições/Lei Orgânica), sendo que o exercício desse poder parece ter se manifestado com intensidade bastante variável.

Da análise dos dados levantados, constata-se haver constituições que em seus quase 30 anos de vigência sofreram emendas relativamente pouco numerosas, e outras que sofreram um número elevado de modificações.

Considerando os dados relativos a todos os Estados, o número total de emendas às constituições subnacionais desde a criação das mesmas até 2019 foi de 1794 emendas, o que corresponde a uma média aproximada de 59,8 emendas por ano (uma vez que nem todas as constituições possuem o mesmo tempo de vigência, como visto, variando de 26 a 30 anos, razão de o dado ser meramente aproximado). Tal montante de emendas significa que cada constituição sofreu em média aproximadamente 66 Emendas.

A Constituição estadual que sofreu menor número de emendas é a Constituição do Estado do Rio Grande do Norte, emendada apenas 14 vezes até 2015, seguida pele Constituição do Estado da Bahia, que até 2018 foi formalmente modificada apenas 25 vezes. As constituições alagoana e tocantinense foram reformadas 41 e 37 vezes, respectivamente (última emenda em Alagoas ocorrida no ano de 2016 e em Tocantins no ano de 2019). Tais constituições parecem ostentar, portanto, grau razoavelmente elevado de estabilidade, embora não tenha sido possível examinar, ainda, as possíveis causas de tal fenômeno.

A Constituição com maior número de modificações formais é a do Estado de Rondônia, com impressionantes 132 emendas até o ano de 2018. É seguida, nesse sentido, pelas constituições do Amazonas (108 emendas até 2018), Espírito Santo (108 emendas até 2017), Minas Gerais (99 emendas até 2019) e pela Lei Orgânica do Distrito Federal (112 emendas até o ano de 2018). Essas constituições parecem encontra-se no extremo oposto do espectro de estabilidade constitucional em relação ao grupo anterior, embora igualmente ainda não tenha sido possível investigar as possíveis causas do fenômeno.

Todas as demais constituições Estaduais possuem mais de 40 e menos de 100 Emendas. Enquadram-se nessa categoria as constituições do Acre (49 até 2017), Amapá (58 até 2018), Ceará (94 até 2018), Goiás (58 até 2018), Maranhão (80 até 2018), Mato Grosso (82 até 2019), Mato Grosso do Sul (79 até 2018), Pará (63 até 2015), Paraíba (42 até 2016), Paraná (42 até 2018), Pernambuco (44 até 2018), Piauí (51 até 2018), Rio de Janeiro (71 até 2017), Rio Grande do Sul (76 até 2019), Roraima (60 até 2018), Santa Catarina (75 até 2017), São Paulo (47 até 2019), Sergipe (47 até 2017). ${ }^{7}$

No presente estágio da pesquisa não foi possível levar a cabo uma análise qualitativa das emendas, e tampouco buscar identificar fatores capazes de explicar as variações de estabilidade existentes entre as diferentes constituições, limitando-se por ora os resultados aos aspectos quantitativos aqui consignados.

7 As últimas datas apontadas correspondem sempre à aprovação da última emenda à constituição em questão localizada em pesquisa junto aos órgãos legislativos estaduais/distrital. 


\subsection{TÍTULOS E ARTIGOS: ANÁLISE QUANTITATIVA}

Quando se examina o número de títulos contemplados pela maioria das constituições estaduais (assim entendidas suas subdivisões primárias em termos de sistematização), constata-se que a média, consideradas todas as constituições, é de 8 títulos, havendo, porém, discrepâncias bastante proeminentes.

Contemplam 7 Títulos as Constituições dos Estados do Acre, Goiás, Paraná, Rondônia, Roraima e São Paulo; 8 Títulos as dos Estados do Ceará, Pernambuco, Rio Grande do Norte, Rio Grande do Sul e Sergipe, bem como a Lei Orgânica do Distrito Federal. Contam com 9 Títulos, por sua vez, as Constituições de Alagoas, Espírito Santo, Maranhão, Paraíba e Piauí; e com 10 Títulos as cartas constitucionais do Amapá, do Pará, do Rio de Janeiro e de Santa Catarina.

Alguns Estados discrepam da maioria, ao contemplar número reduzido ou superior à média. É o caso das Constituições do Amazonas e da Bahia e de Mato Grosso do Sul, com 6 Títulos cada uma, de Mato Grosso e Minas Gerais, com 5 Títulos cada. No extremo oposto, a Constituição do Estado do Tocantins conta com 16 Títulos.

Quanto à extensão ou número de artigos no texto constitucional, as Constituições Estaduais brasileiras revelam-se igualmente variáveis, existindo cartas constitucionais que contemplam algo mais do que uma centena de artigos, e outras que ultrapassam as três centenas. As constituições com menor número de artigos em seu texto são a dos Estados do Rio Grande do Norte e do Tocantins, com 162 artigos; a mais extensa é a Constituição do Estado do Rio de Janeiro, com 369 artigos, seguida pelas Constituições do Ceará (336 artigos), Mato Grosso (357 artigos) e pela Lei Orgânica do Distrito Federal (366 artigos). Constata-se que em nível estadual, a despeito da inspiração frequente do constituinte estadual na Constituição Federal, verificam-se constituições prolixas ou analíticas e constituições mais sintéticas ou concisas.

A maioria das Constituições examinadas, no entanto, situa-se no intervalo entre 200 a 300 artigos (Acre, Alagoas, Amazonas, Bahia, Espírito Santo, Maranhão, Mato Grosso do Sul, Paraíba, Paraná, Pernambuco, Piauí, Rio Grande do Sul, Rondônia). Os Estados de Minas Gerais, São Paulo e Sergipe inserem-se nesta categoria, embora se aproximem bastante dos 300 artigos (com 299, 297 e 288 artigos em seus textos constitucionais, respectivamente).

A média aritmética, considerados todos os textos constitucionais estaduais (total de 7399 artigos), é de 274 artigos (sem abranger itens especificamente voltados às disposições transitórias ou gerais e congêneres).

Algumas constituições ficam abaixo dos 200 artigos, além das já citadas (Rio Grande do Norte e Tocantins, ambas com 162 artigos): é o caso da carta política de Goiás, com cerca de 181 artigos, Roraima, com 184, e Santa Catarina, com 196. Note-se que o número de artigos aqui referidos é aproximado, uma vez que é freqüente a utilização de acréscimo de dispositivos constitucionais interpolados seguidos de letras alfabéticas (como o art. 181-A, na Constituição de Roraima), de modo que a constatação do número exato de artigos pressuporia uma contagem, e o 
levantamento fez-se, no momento, pelo exame do artigo final do texto constitucional. ${ }^{8}$

Consigne-se que tais dados dizem respeito exclusivamente ao texto constitucional, excluídos os atos de disposições constitucionais transitórias e equivalentes. Todas as Constituições possuem título específico para as disposições transitórias ou análogo. Os ADCTs são igualmente variáveis em termos de extensão, indo desde 26 artigos (Tocantins) até 140 artigos (Minas Gerais), ficando a maioria em algumas dezenas de artigos, não ultrapassando, em geral, uma centena de disposições.

\subsection{TÍTULOS E MATÉRIAS: ANÁLISE QUALITATIVA}

Os títulos das cartas constitucionais estaduais, cuja variabilidade numérica já foi explorada, representam divisões primárias daquelas, como já dito, nos moldes do que ocorre com a Constituição Federal. As matérias distribuídas entre tais títulos e suas denominações, claramente influenciadas pela Constituição Federal, ostentam certa convergência, sem prejuízo de algumas variações importantes.

Boa parte das constituições estaduais contempla em seu Título I os princípios constitucionais fundamentais. Tal título é intitulado "Dos Princípios Fundamentais" em 13 constituições (Alagoas, Amapá, Bahia, Ceará, Pará, Paraíba, Pernambuco, Piauí, Rio de Janeiro, Rio Grande do Norte, Rio Grande do Sul, Roraima e Santa Catarina). Quatro constituições adotam a denominação "Da organização do Estado" ou "Da organização do Estado e dos municípios" para o título inaugural (Goiás, Paraná, Rondônia e Tocantins), sendo intitulado, na Constituição do Estado de Mato Grosso do Sul, "Dos princípios constitucionais fundamentais". Duas cartas intitulam o Título I de "Disposições preliminares” (Maranhão e Minas Gerais).

A matéria relativa à organização do Estado encontra-se contemplada no Título II de algumas constituições (Mato Grosso do Sul, Pernambuco, Rondônia e Sergipe), assim como na Lei Orgânica do Distrito Federal. Em outras constituições a organização do Estado (e, eventualmente, dos municípios) é contemplada no Título III (assim ocorre em 16 constituições: Amapá, Amazonas, Bahia, Ceará, Espírito Santo, Maranhão, Mato Grosso, Minas Gerais, Pará, Paraíba, Piauí, Rio de Janeiro, Rio Grande do Norte, Roraima, Santa Catarina, São Paulo e Tocantins). Algumas constituições possuem capítulo dedicado ao tema de defesa do Estado (Título IV das cartas acreana e sergipana; Título V da Constituição maranhense).

Nas demais constituições, a denominação dos títulos iniciais varia, assim como, em parte, a matéria neles tratadas. De modo geral, constata-se que tais títulos tratam de princípios constitucionais estaduais, ou de normas organizatórias do Estado e, eventualmente, dos municípios. Em um caso, na Constituição sergipana, o Título I trata do Estado e dos direitos e garantias, tema normalmente constante no Título II de diversas outras leis fundamentais estaduais.

8 Pesquisas ulteriores serão feitas com base na contagem de caracteres ou palavras, para aprimorar a fidelidade dos resultados. Tais dados serão associados aos aqui expostos, de modo a permitir melhor compreensão da questão da extensão das cartas constitucionais estaduais, assim como da possível relação entre extensão e estabilidade (frequência das emendas), entre outros aspectos. 
A temática da organização dos poderes tende a aparecer igualmente nos títulos iniciais, por vezes no Título II (tal ocorre com as cartas de Rondônia, São Paulo e Tocantins), no Título III (Acre, Alagoas, Distrito Federal, Paraná, Rio Grande do Sul e Sergipe), no Título IV (Bahia, Espírito Santo, Maranhão, Mato Grosso do Sul, Piauí, Rio de Janeiro, Rio Grande do Norte, Roraima e Santa Catarina) ou no Título V (Amapá, Ceará, Pará e Paraíba), não sendo formalmente constituída em título em algumas constituições, normalmente sendo em tais casos veiculada em outro título, como no relativo à organização do Estado.

Algumas constituições estaduais contemplam títulos específicos dedicados à temática da organização dos municípios (Ceará, Título IV; Goiás, Título II; Mato Grosso, Título IV; Pará, Título IV; Pernambuco, Título III; Rondônia, Título III; São Paulo, Título IV, Rio de Janeiro, Título IX) ou à temática da administração pública (Goiás, Mato Grosso do Sul, ambos no Título III; Paraíba e Paraná, ambos no Título IV). O Título VI da Constituição catarinense é intitulado "dos assuntos municipais e microrregionais".

Todas as constituições examinadas contemplam a matéria relativa à ordem econômica e/ou social, conjunta ou separadamente, em diferentes tópicos: Título V (Amazonas e Mato Grosso); Títulos V e VI (Alagoas, DF, Paraná); Título VI (Acre, Bahia, Goiás, Mato Grosso do Sul, Rondônia); Títulos VI e VII (Pernambuco, Rio Grande do Norte, Rio Grande do Sul, São Paulo, Sergipe); Títulos VII e VIII (Amapá, Espírito Santo, Paraíba, Piauí, Rio de Janeiro). Alguns temas por vezes acompanham o Título dedicado à ordem econômica temas como as finanças (Espírito Santo, Rio Grande do Norte, Rio de Janeiro, Roraima, Santa Catarina) ou o meio ambiente (Distrito Federal, Pará).

Evidentemente as cartas constitucionais estaduais contemplam um ou mais títulos sobre tributação, orçamento e finanças públicas, conjunta ou separadamente (Título IV: Amazonas, Alagoas, DF, Goiás, Paraná, Rondônia, Tocantins; Título V: Acre, Bahia, Mato Grosso do Sul, Pernambuco, Rio Grande do Norte, Rio Grande do Sul, Roraima, São Paulo, Sergipe; Título VI: Amapá, Espírito Santo, Maranhão, Paraíba, Piauí, Rio de Janeiro; Título VII: Ceará, Pará e Santa Catarina).

Algumas cartas estaduais contemplam título dedicado à segurança pública: Piauí, Rio de Janeiro e Santa Catarina (Título V); Pará (Título VI); Alagoas (Título VII); Tocantins (Título XI). Diversas cartas possuem títulos peculiares, frequentemente vinculados à ordem social e/ou aos direitos e garantias fundamentais: Título IV da Constituição mineira (Da Sociedade); Título V da Constituição do Espírito Santo (Da defesa do cidadão e da sociedade); Título VIII da Constituição cearense (Das responsabilidades culturais, sociais e econômicas). Diversas constituições contemplam temas como disciplina urbanística e/ou agrária, política agrícola/ fundiária, e reforma agrária (Títulos VII e XII da Constituição do Estado do Tocantins; Título VIII da Constituição alagoana).

Nessa categoria merece destaque a Constituição tocantinense, que contempla diversos títulos peculiares e conexos à ordem econômica e social e aos direitos fundamentais: Título VI (Dos sistemas de distribuição de renda e equilíbrio social); Título VIII (Do sistema de 
defesa das minorias e proteção de associações); Título IX (Defesa do cidadão e sistema de proteção ao consumidor); Título X (Meio ambiente); Título XIII (Dos direitos e de proteção à infância, à mulher e à velhice); Título XIV (Da Educação, cultura, saúde, ciência e tecnologia), além dos já citados títulos VII, XI e XII). ${ }^{9}$

A temática dos direitos e garantias fundamentais, tratada no título inaugural da Constituição do Sergipe, aparece predominantemente nos títulos II de diversas outras: Amapá, Amazonas, Bahia, Ceará, Espírito Santo, Maranhão, Mato Grosso, Minas Gerais, Pará, Paraíba, Piauí, Rio de Janeiro, Rio Grande do Norte, Roraima e Santa Catarina. Constata-se que todas estas cartas, bem como a de Sergipe (16 constituições estaduais) possuem título especificamente voltado aos Direitos e Garantias fundamentais estaduais, como denominação variável (predominantemente "Dos Direitos e Garantias Fundamentais", eventualmente "Direitos, Garantias e Deveres - Mato Grosso - ou apenas "Direitos e Garantias" (Minas Gerais, Piauí, Roraima e Santa Catarina). Na Constituição do Estado de Rondônia, o Título V trata "Dos Direitos Individuais e Coletivos".

A inexistência de título próprio dedicado aos Direitos e Garantias Fundamentais nas demais constituições não significa, entretanto, que as mesmas não contemplem tais instituições, mas apenas que adotam a técnica de contemplar as mesmas de maneira dispersa ao longo do texto, especialmente nos Títulos dedicados à Ordem Econômica e Social, nos quais costumam abundar disposições consagradoras de direitos e liberdades fundamentais, especialmente direitos de bemestar (o que ocorre inclusive nas cartas que contemplam título próprio). ${ }^{10}$

Faz-se necessário registrar que neste primeiro momento da pesquisa foram examinadas apenas as divisões primárias das cartas estaduais e distrital, sendo que em fase ulterior da pesquisa serão examinadas as divisões secundárias e terciárias existentes, notadamente seções e capítulos, tanto do ponto de vista quantitativo (número de artigos/extensão) quanto do ponto de vista qualitativo (matérias versadas).

Após o panorama proporcionado pelos temas examinados no presente tópico, por meio do método estrutural-comparativo (SGARBOSSA, 2008), revela-se necessário verticalizar o estudo, analisando o pouco estudado tema dos direitos e garantias fundamentais estaduais no Brasil, o que se passa a fazer no próximo tópico.

\section{DIREITOS FUNDAMENTAIS ESTADUAIS NO BRASIL: TEORIA E VISÃO GERAL}

Ensina José Afonso da Silva, ao discorrer sobre o conteúdo das constituições

9 A maioria das cartas possui Títulos destinados a disposições constitucionais gerais ou finais: Acre (Título VII);

Alagoas e Amapá (Título IX); Amazonas (Título VI); Distrito Federal (Título VIII); Espírito Santo (Título IX); Goiás (Título VII); Maranhão (Título IX); Minas Gerais (Título V); Pará (Título X); Paraíba (Título IX); Paraná (Título VII); Pernambuco (Título VIII); Piauí (Título IX); Rio de Janeiro (Título X); Rio Grande do Norte (Título VIII); Rio Grande do Sul (Título VIII); Rondônia (Título VII); Santa Catarina (Título X); São Paulo (Título VIII); Sergipe (Título VIII) e Tocantins (Títulos XV e XVI). As Constituições da Bahia, Ceará, Mato Grosso, Mato Grosso do Sul e Roraima, no entanto, não possuem título similar.

10 Fenômeno semelhante ocorre nos EUA, onde, a despeito da difundida tese do excepcionalismo da tradição constitucional estadunidense, que seria infensa a direitos de igualdade, constatam-se diversos direitos positivos ou prestacionais nas 50 cartas estaduais. Sobre o tema, conferir ZACKIN, obra citada nas referências. 
estaduais no Brasil, que estas, assim como a Constituição Federal, são compostas por elementos dogmáticos (ou limitativos), orgânicos e sócio-ideológicos, consistindo os primeiros nos direitos fundamentais. A despeito da visão restritiva do autor quanto à amplitude da competência estadual na matéria, reconhece ele a existência de direitos fundamentais estaduais na ordem constitucional pátria (SILVA, 2011).

A literatura jurídica brasileira filia-se majoritariamente ao conceito formal de direitos fundamentais, como é sabido (SARLET, 2012). Assim, consideram-se direitos fundamentais apenas e tão-somente os direitos públicos subjetivos estabelecidos por normas de hierarquia constitucional, recusando-se tal natureza a outros direitos previstos em nível infraconstitucional ou supranacional, que tendem a ser concebidos como direitos subjetivos em paridade hierárquiconormativa com aqueles estabelecidos por normas infraconstitucionais ou, no máximo, em nível supralegal (HC 87.585-8/TO).

Tal concepção, associada ao caráter centralizador da federação brasileira, aqui já referenciado, tendem a evidenciar como direitos fundamentais apenas aqueles previstos na Constituição Federal, sejam aqueles constantes no amplo rol do Título II (arts. $5^{\circ}$ a 17), sejam os direitos dispersos ao longo do texto constitucional federal (CANOTILHO, 2003).

Mais recentemente, com a aprovação de instrumentos internacionais pelo procedimento previsto no $\S 3^{\circ}$ do art. $5^{\circ}$ (introduzido no texto constitucional pela Emendas Constitucional n. 45/2004), passou-se a considerar também como direitos fundamentais em sentido formal os direitos subjetivos previstos em alguns instrumentos ratificados pelo Estado brasileiro (nomeadamente, a Convenção sobre os Direitos das Pessoas com Deficiência de 2007, aprovada pelo Decreto Legislativo n. 186/2008 e promulgada pelo Decreto n. 6.949/2009, bem como do Tratado de sobre o acesso de pessoas cegas a obras publicadas, de 2013, aprovado pelo Decreto Legislativo n. 261/2015 e promulgado pelo Decreto n. 9.522/2018).

Ocorre que, considerando o poder constituinte derivado decorrente de que gozam os Estados brasileiros (art. 25), e tendo os mesmos adotado suas constituições majoritariamente em 1989 (24 unidades da federação ao todo), conforme previsto no art. 11 do ADCT, e os demais em 1991 ou 1993 (3, a saber, Amapá, Roraima e DF), deve-se acrescentar ao conjunto de direitos fundamentais em sentido formal todos aqueles direitos públicos subjetivos previstos nas constituições estaduais, seja em título próprio, seja dispersos ao longo dos textos constitucionais estaduais.

Aqui novamente as diferenças entre o sistema jurídico brasileiro e outros sistemas estrangeiros, notadamente o norte-americano, se fazem notar, cabendo quanto ao particular uma importante observação.

Todas as 50 constituições estaduais norte-americanas contemplam um Bill of rights que, em muitos casos, é bastante diverso do federal, podendo conter diversos direitos fundamentais inexistentes em nível federal. ${ }^{11}$ Basta recordar o denominado Three Rights Movement

11 José Adércio de Leite Sampaio observa que nas federações com menor autonomia local as constituições subnacionais tendem a contemplar conjuntos menos inovadores e detalhados de direitos fundamentais, como é o caso do Brasil (consultem-se as referências bibliográficas ao final). 
que, com maior sucesso em alguns Estados norte-americanos e menor em outros, conseguiu constitucionalizar, em nível subnacional, inclusive direitos prestacionais relativos à educação, ao trabalho e ao meio-ambiente naquele país, o que infirma em boa medida a tese do excepcionalismo constitucional norte-americano (ZACKIN, 2013). ${ }^{12}$

No Brasil o panorama é diverso, mas nem por isso o tema é desimportante ou desinteressante, tanto do ponto de vista teórico quanto do prático. Das cartas constitucionais estaduais atualmente vigentes, 16 possuem título especificamente dedicado aos direitos fundamentais, como já registrado, normalmente o Título II ou I (a saber, as constituições do Amapá, Amazonas, Bahia, Ceará, Espírito Santo, Maranhão, Mato Grosso, Minas Gerais, Pará, Paraíba, Piauí, Rio de Janeiro, Rio Grande do Norte, Roraima, Santa Catarina e Sergipe).

Além disso, mesmo nas constituições subnacionais que não contemplam título específico para direitos e garantias fundamentais, é possível encontrar os mesmos dispersos ao longo do texto, notadamente em títulos, capítulos ou seções como aqueles destinados à tributação, à ordem econômica e social, família, idoso, gestante, criança e adolescente, cultura, desporto, educação, meio-ambiente, entre outros, também conforme já referido anteriormente.

Além disso, apesar do exame de tais direitos em espécie revelar um alto grau de dependência do texto constitucional federal (numerosas normas de imitação ${ }^{13}$, com recepção material de direitos federais pelos textos estaduais), havendo significativa repetição de direitos fundamentais federais idênticos ou simples remissão (reenvio formal) ao texto federal (SAMPAIO, 2019), há diversas constituições estaduais nas quais inovou o constituinte, prevendo direitos sem paralelo na órbita federal.

Acrescente-se a isso, ainda, que mesmo os direitos fundamentais duplicados nas esferas federal e estadual podem representar problemas teóricos e práticos importantes. A título de ilustração, registre-se que nem sempre tais direitos serão idênticos, podendo possuir áreas ou âmbitos de proteção distintos, o que pode gerar questionamentos importantes acerca do critério para a solução de conflitos, colisão ou concorrência (SGARBOSSA, 2008a; DIMOULIS e MARTINS, 2009) entre direitos fundamentais estaduais e federais, ensejando diversas possibilidades, entre as quais o estabelecimento de uma primazia incondicionada dos federais sobre os estaduais ou viceversa, ou a aplicação de um critério de precedência condicionada, tal como o critério da norma mais favorável ao titular ${ }^{14}$.

Além desse aspecto, outros podem ser destacados, tal como a possibilidade de 12 As declarações de direitos estaduais revestiram-se de particular importância nos EUA notadamente no período de 1791 a 1868, dado que a extensão do Bill of Rights federal aos Estados só se deu expressamente pela XIV Emenda,

do último ano, sendo os poderes estaduais limitados exclusivamente pelas constituições estaduais e pelos direitos subjetivos nelas previstas neste longo lapso temporal. Nesse sentido, ZACKIN, na obra citada nas referências bibliográficas.

13 Poder-se-ia discutir se as normas estabelecedoras de direitos fundamentais federais copiadas em nível estadual seriam normas de imitação ou normas de reprodução obrigatória, no sentido impingido pela doutrina (ver, por todos, LEONCY, op. cit.). Embora seja evidente que o cumprimento das normas de direitos fundamentais por todos os entes da federação seja impositivo, esposa-se aqui entendimento no sentido que se compreende como mais compatível com a autonomia dos entes federados, ou seja, como normas constitucionais de imitação espontânea pelos Estados, e não de reprodução obrigatória.

14 Trata-se de problema clássico quando se aborda a proteção de direitos multinível, seja na conexão entre o nível supranacional e o nível nacional; seja na conexão entre o nível nacional e o subnacional. Problema análogo enfrentou o STF no famoso leading case do habeas corpus 87.585-8/TO. Sobre o tema consultar SARLET, op. cit. 
permanência de direitos inicialmente duplicados em nível apenas estadual em caso de revogação de direitos em nível federal. Nos EUA os direitos fundamentais estaduais desempenharam um papel determinante em certos períodos, como, por exemplo, entre 1791, data de criação do Bill of Rights, e 1868, data da XIV Emenda (Equal Protection Clause). Em tal período, como os direitos fundamentais federais criados em 1791 eram compreendidos como oponíveis apenas às autoridades federais até a XIV Emenda, que finalmente o estendeu expressamente também aos Estados, foi crucial o papel dos direitos fundamentais estaduais (ZACKIN, 2013). ${ }^{15}$

No Brasil, a despeito da previsão dos direitos e garantias individuais como limite material ao poder de reforma da constituição (art. $60 \S 4^{\circ}$, IV), a manifestação de um novo poder constituinte originário, ou mesmo uma eventual aceitação pelo Supremo Tribunal Federal da tese da dupla revisão ${ }^{16}$ poderiam acarretar a revogação de direitos fundamentais do texto constitucional federal, incrementando a importância mesmo de disposições constitucionais estaduais originalmente duplicadas a partir do texto federal.

Feita tal análise geral, a título de contextualização e exame preliminar do interessante tema dos direitos e garantias fundamentais estaduais ${ }^{17}$, convém examinar alguns direitos fundamentais estaduais em espécie, o que se fará no próximo tópico do presente estudo.

\section{ANÁLISE DE ALGUNS DIREITOS FUNDAMENTAIS ESTADUAIS EM ESPÉCIE}

Após o breve panorama comparativo e a visão geral precedentes, revela-se oportuno examinar alguns dos direitos fundamentais estaduais previstos nas diversas constituições dos Estados-membros da federação brasileira e na Lei Orgânica do Distrito Federal (dada a natureza híbrida ou semiconstitucional da última), embora sem pretensão de exaustão, destacando alguns dos casos mais relevantes ou interessantes.

Deve-se observar desde logo que do exame das diversas constituições e da LODF identificam-se algumas situações principais, a saber: a) a presença de direitos fundamentais total ou parcialmente coincidentes com os arrolados na Constituição Federal (SAMPAIO, 2019); b) a presença de direitos fundamentais estaduais específicos, ou seja, que não encontram paralelo na ordem constitucional federal.

Uma terceira situação digna de nota, ainda, é a da presença, em diversas constituições estaduais, de uma cláusula geral de reconhecimento e proteção dos direitos fundamentais federais, ou seja, uma situação de remissão ou reenvio formal feito pelas constituições estaduais à constituição federal (SAMPAIO, 2019), verdadeira cláusula de abertura estadual a

15 Além disso, é digno de nota que nos EUA as normas estaduais estabelecedoras de direitos fundamentais foram objeto de importante concretização judicial, de modo que parece bastante diverso do que vem ocorrendo no Brasil. Sobre o tema, consulte-se o artigo de Stewart G. Pollock (vide referências, ao final).

16 Sobre o tema, conferir SILVA, Virgílio Afonso da. Ulisses, as sereias e o poder constituinte derivado: sobre a inconstitucionalidade da dupla revisão e da alteração do quorum de 3/5 para a aprovação de emendas constitucionais. Revista de Direito Administrativo, n. 226, 2001, pp. 11-32.

17 Pode causar espécie à primeira vista falar em garantias fundamentais estaduais diante da restrição constitucional à legislação estadual em matéria processual (art. 22, I), a despeito do disposto no art. 24, XI da CF. No entanto, basta recordar que as garantias não necessariamente precisam ostentar caráter jurisdicional, para que reste evidenciada a inexistência de qualquer impropriedade em tal conceito. 
conectar as ordens constitucionais subnacional e federal. Examinaremos cada uma dessas situações separadamente nos subitens a seguir.

\subsection{CLÁUSULA DE ABERTURA OU CLÁUSULA GERAL DE RECONHECIMENTO E PROTEÇÃO DE DIREITOS FUNDAMENTAIS FEDERAIS NAS ORDENS CONSTITUCIONAIS ESTADUAIS}

Como mencionado no item anterior, diversas constituições estaduais contemplam uma espécie de cláusula de abertura, mais ou menos similar à contida no $\S 2^{\circ}$ do art. $5^{\circ}$ da Constituição Federal vigente. Trata-se de uma cláusula geral que geralmente expressa o reconhecimento, pelo Estado, dos direitos e garantias fundamentais previstos na Constituição Federal, e, ao mesmo tempo, que assegura sua garantia nos limites das competências dos Estados (SAMPAIO, 2019).

Disposições de tal teor são encontradas em diversas constituições estaduais, como as dos Estados do Amazonas (art. $3^{\circ}$ ), de Minas Gerais (art. $4^{\circ}$ ), de Mato Grosso (art. 10), do Pará (art. $5^{\circ}$ ), da Paraíba (art. $3^{\circ}$ ), do Piauí (art. $5^{\circ}$ ), do Rio Grande do Norte (art. $3^{\circ}$ ) e de Sergipe $\left(\operatorname{art} .3^{\circ}\right)$.

Tais cláusulas revelam-se particularmente interessantes porque parecem estabelecer uma relação entre ordenamento constitucional estadual e ordenamento constitucional federal, caracterizando-se como norma de reenvio formal, o que fará com que possam ter importante impacto em questões como, por exemplo, controle estadual de constitucionalidade, considerando-se o regime jurídico conferido às normas de imitação pela doutrina e especialmente pela jurisprudência do STF (LEONCY, 2007).

A referida cláusula encontra-se, por exemplo, no artigo $3^{\circ}$ da Constituição do Estado do Amazonas, que estabelece que "o Estado, nos limites de sua competência, assegura, em seu território, a brasileiros e estrangeiros, a inviolabilidade dos direitos e garantias fundamentais declarados na Constituição da República." Como se percebe, é praticamente uma norma de reenvio formal a conectar as ordens constitucionais federal e estadual. Esta norma repete-se em diversas constituições estaduais, com variações maiores ou menores, como se verá. Disposição de idêntico teor literal encontra-se, por exemplo, na Constituição vigente do Estado de Minas Gerais (art. $4^{\circ}$, caput), Piauí (art. $5^{\circ}$ ), Rio Grande do Norte (art. $3^{\circ}$ ) e Sergipe (art. $\left.3^{\circ}\right) .^{18}$

Algumas constituições contemplam dispositivo de teor análogo, embora com importantes modificações. É o caso a Constituição do Estado de Mato Grosso, em seu artigo 10, cujo teor convém transcrever:

18 Constituição do Estado de Minas Gerais: “Art. $4^{\circ}$ - O Estado assegura, no seu território e nos limites de sua competência, os direitos e garantias fundamentais que a Constituição da República confere aos brasileiros e aos estrangeiros residentes no País." Constituição do Estado do Piauí: Art. $5^{\circ} \mathrm{O}$ Estado assegura, no seu território e nos limites de sua competência, a inviolabilidade dos direitos e garantias fundamentais que a Constituição Federal confere aos brasileiros e aos estrangeiros residentes no país. Constituição do Estado do Rio Grande do Norte: "Art. $3^{\circ} \mathrm{O}$ Estado assegura, nos limites de sua competência, os direitos e garantias fundamentais que a Constituição Federal reconhece a brasileiros e estrangeiros." Constituição do Estado de Sergipe: Art. $3^{\circ}$. O Estado assegura por suas leis e pelos atos dos seus agentes, além dos direitos e garantias individuais previstos na Constituição Federal e decorrentes do regime e dos princípios que ela adota, ainda os seguintes: (...) 
"O Estado de Mato Grosso e seus Municípios assegurarão, pela lei e pelos atos dos agentes de seus Poderes, a imediata e plena efetividade de todos os direitos e garantias individuais e coletivas, além dos correspondentes deveres, mencionados na Constituição Federal, assim como qualquer outro decorrente do regime e dos princípios que ela adota, bem como daqueles constantes dos tratados internacionais em que a República Federativa do Brasil seja parte, nos termos seguintes: (...)."

Nota-se que a referida disposição do constituinte estadual mato-grossense, além de corresponder à já referida cláusula geral de reconhecimento e proteção de direitos fundamentais federais, incorpora ainda disposição equivalente à cláusula de abertura prevista no $\S 2^{\circ}$ do art. $5^{\circ}$ da Constituição da República de 1988, caracterizando interessante hipótese de conexão não apenas da ordem constitucional subnacional com a ordem constitucional federal, mas, também, com a ordem jurídica supranacional.

Registre-se, novamente, que considerando o fato de que tal tipo de cláusula estabelece uma conexão multinível entre as ordens jurídicas subnacional, nacional (federal) e supranacional, diversos fenômenos interessantes poderão dela decorrer. Disposição similar encontra-se na Constituição do Estado da Paraíba, cujo artigo $3^{\circ}$ prevê:

“Art. $3^{\circ} \mathrm{O}$ Estado e os Municípios asseguram, em seus territórios e no limite de suas competências, a plenitude e inviolabilidade dos direitos e garantias fundamentais que a Constituição Federal reconhece e confere aos brasileiros e aos estrangeiros residentes no País, bem como outros quaisquer decorrentes do regime e dos princípios adotados."

A cláusula de abertura estadual encontra-se ainda em outras cartas constitucionais subnacionais, como a Constituição do Estado do Pará, cujo artigo $5^{\circ}$, caput, estabelece:

"Todos são iguais perante a lei, sem distinção de qualquer natureza, garantindose aos brasileiros e aos estrangeiros residentes no Estado a inviolabilidade do direito à vida, à liberdade, à igualdade, à segurança e à propriedade, nos termos da Constituição Federal e desta Constituição."

Além de constituir importante norma de imitação ${ }^{19}$ do caput do art. $5^{\circ}$ da $\mathrm{CF} / 88$, que duplica na ordem constitucional parcial (estadual) direitos fundamentais previstos na ordem jurídica global (federal), a norma caracteriza-se como de reenvio ao consagrar a expressão "nos termos da Constituição Federal", aplicando-se a ela o mesmo já dito sobre as demais normas aqui já examinadas.

Sem pretender aqui exaurir o tema em toda sua complexidade em termos de consequências, cabe observar, conclusivamente, que tal norma parece claramente autorizar a

19 A menos que se considerem tais normas como normas constitucionais federais de reprodução obrigatória, o que não parece constituir a melhor orientação, conforme nota anterior. 
adoção da concepção segundo a qual o rol federal de direitos fundamentais deve ser interpretado como "piso" ou standard mínimo de direitos, passível de acréscimo e complementação pelo poder constituinte dos Estados (SILVA, 2011), o que terá consequências importantes em situações de concorrência de direitos fundamentais (SGARBOSSA, 2008). ${ }^{20}$

Outros aspectos que aqui não poderão ser explorados por questões de limites de espaço. Consigne-se, por exemplo, que diversas constituições subnacionais contemplam disposições garantidoras da eficácia dos direitos fundamentais, como faz, por exemplo, a Constituição do Estado da Paraíba, em seu artigo $3^{\circ}, \S 1^{\circ}$, ao prever a destituição do mandato administrativo, cargo ou função de direção da administração direta ou indireta de agente público que, injustificadamente e por mais de 90 dias a contar do requerimento do interessado, deixa de sanar omissão inviabilizadora do exercício de direito constitucional (SAMPAIO, 2019). ${ }^{21}$

Essa disposição revela-se particularmente relevante não apenas por constituir um mecanismo sem paralelo na ordem constitucional federal (garantia política de eficácia das normas constitucionais estabelecedoras de direitos fundamentais) ${ }^{22}$, mas também por constituir exceção à regra no controle de constitucionalidade contemporâneo.

Como se sabe, o controle de regularidade das normas e atos jurídicos em geral pode ser primário (incidente sobre o agente) ou secundário (incidente sobre a validade do ato), e o controle de constitucionalidade contemporâneo tem tendido de maneira bastante preponderante a ser secundário, fulminando atos inconstitucionais com invalidade jurídica (nulidade ou anulabilidade), mas raramente acarretando punição do agente responsável pela inconstitucionalidade. O inteligente preceito constitucional paraibano conecta controle secundário e controle primário para combater omissão administrativa inconstitucional, no que é merecedor de aplausos.

Examinadas brevemente as cláusulas de reenvio e/ou de abertura estaduais, convém realizar algumas reflexões sobre a temática dos direitos fundamentais estaduais coincidentes com os federais (como os inscritos no caput do art. $5^{\circ}$ da Constituição paraense, retro) para, após, examinar o tema dos direitos fundamentais estaduais não-coincidentes ou específicos.

\subsection{DIREITOS FUNDAMENTAIS ESTADUAIS TOTAL OU PARCIALMENTE COINCIDENTES COM OS FEDERAIS}

20 Como ensina Pinto Ferreira quanto ao Direito Constitucional Estadual norte-americano, "as constituições dos States também têm as suas declarações de direitos ou Bill of rights. Tais declarações de direitos também são previstas no corpo da Constituição Federal, de sorte que os cidadãos dos States se encontram protegidos por duas

ordens legais fundamentais, a da União e a dos Estados-membros.” (FERREIRA, 1964).

21 "Art. $3^{\circ} \mathrm{O}$ Estado e os Municípios asseguram, em seus territórios e no limite de suas competências, a plenitude e inviolabilidade dos direitos e garantias fundamentais que a Constituição Federal reconhece e confere aos brasileiros e aos estrangeiros residentes no País, bem como outros quaisquer decorrentes do regime e dos princípios adotados.

$\S 1^{\circ}$ Incide na penalidade de destituição de mandato administrativo, de cargo ou função de direção, em órgão da administração direta ou indireta, o agente público que, dentro de noventa dias do requerimento do interessado, deixar, injustificadamente, de sanar omissão inviabilizadora do exercício de direito constitucional.»

22 Como ensina Marcos Del Rosario Rodríguez, a proteção dos direitos fundamentais estabelecidos em constituições locais constituiria um dos temas cardeais do Direito Processual Constitucional, pois embora aquelas reconheçam tais direitos públicos subjetivos de hierarquia constitucional normalmente carecem de garantias adequadas: "En las constituciones locales aunque exista un reconocimiento expreso de derechos fundamentales, la eficacia y la vigencia de estos se vuelve algo compleja, pues en la mayoría de estos no se han creado modelos que garanticen su protección." (RODRÍGUEZ, 2009, p. 217). 
Como já registrado, frequentemente as constituições estaduais brasileiras apresentam direitos fundamentais que ostentam de significativo grau de semelhança ou mesmo constituem cópias idênticas aos direitos assegurados pela Constituição.

É o caso, por exemplo, do artigo $5^{\circ}$ da Constituição do Estado do Amapá, que, reproduzindo disposição da Constituição Federal (art. $5^{\circ}$ ), estabelece a igualdade de todos perante a lei, sem distinção de qualquer natureza. Outro caso consiste no artigo $6^{\circ}$ da constituição do Estado do Pará que, ao regular o exercício da soberania popular por meio de plebiscito, referendo e iniciativa popular, reproduz a norma constante do art. 14 da Constituição Federal.

O Estado de Tocantins, em seu artigo 109, estatui, assim como no artigo $5^{\circ}$, XXXII da Constituição da República, a defesa do consumidor. No mesmo sentido é disposição da Constituição do Estado do Rio de Janeiro (art. 63). A constituição paraibana assegura ao preso o respeito à integridade física e moral em seu artigo $3^{\circ} \S 8^{\circ}$, "a", de maneira similar ao disposto no artigo $5^{\circ}$, XLIX, da CF.

A constituição pernambucana garante a gratuidade do ensino público em seu artigo 178, II, coincidindo assim com o texto da Constituição Federal encontrado no artigo 206, IV. No mesmo sentido, disposição constitucional do Estado de Mato Grosso que prevê, com vistas ao desenvolvimento educacional de seus habitantes, a promoção do direito à educação escolar pública gratuita (art. 237, I).

O Estado do Piauí estabelece direito de segunda geração em seu artigo 203, ao atribuir ao Estado o dever de garantir o direito à saúde de seus cidadãos, de maneira análoga ao direito à saúde previsto no artigo $6^{\circ}$ da Constituição Federal e regulado no Título VIII, Capítulo II, Seção II, arts. 196 a 200 daquela carta.

A Constituição goiana assegura a todos o direito a um meio ambiente ecologicamente equilibrado em seu artigo 127, caput, reproduzindo em âmbito estadual direito fundamental federal (CF/88, artigo 225).

Na Região Sudeste, a constituição mineira garante, em seu artigo 207, o pleno exercício dos direitos culturais, em redação similar pela lei maior no artigo 215, caput. A Constituição paulista, por sua vez, visando promover a integração social, apoia e incentiva o lazer em seu art. 265, repetindo a literalidade do disposto no artigo $217, \S 3^{\circ}$ da Constituição Federal.

A Constituição do Estado do Rio Grande do Sul assegura a redução dos riscos inerentes ao trabalho em seu artigo 29, XII, em disposição equivalente, em sua literalidade, ao artigo $7^{\circ}$, XXII, da Constituição Federal.

Da análise dos dispositivos constitucionais em comento, consistentes em direitos fundamentais estaduais coincidentes com direitos fundamentais federais, encontram-se situações de identidade ou quase-identidade (coincidência total) ou de mera coincidência parcial.

Assim, o direito à redução dos riscos inerentes ao trabalho por meio de normas de saúde, higiene e segurança presente tanto na Constituição Federal (art. $7^{\circ}$, XXII) quanto na Constituição gaúcha (art. 29, XII), como se acaba de ver, é vertido em dispositivos literalmente 
idênticos (tal qual ocorre, também, com o direito ao lazer na Constituição do Estado de São Paulo em cotejo com a Constituição Federal). Trata-se de direitos que, por possuírem fundamento em dispositivos de idêntico teor, parecem possuir idêntico âmbito ou área de proteção, prima facie.

Por outro lado, há casos que beiram a completa identificação literal entre dispositivos federal e estadual, em situação que poderia ser qualificada como de quase-identidade. Serve de exemplo o cotejo do disposto no art. 225 da Constituição da República com o art. 127 da Constituição do Estado de Goiás, já referidos, em que se verificam diferenças mínimas de redação. ${ }^{23}$

De maneira distinta tanto dos casos de identidade quanto de quase-identidade, mais interessantes revelam-se as situações que se poderiam designar como de coincidência parcial de dispositivos. É o caso, por exemplo, do rol de direitos fundamentais sociais garantidos pela Constituição do Estado de Roraima, em seu artigo $5^{\circ}$, quando comparado ao rol constante do artigo $6^{\mathrm{o}}$ da Constituição Federal. Constata-se, em ambos, a proteção do direito à educação, à saúde, ao trabalho, ao lazer, à segurança, à previdência social, à proteção à maternidade e à infância, à assistência aos desamparados. Mas constata-se a ausência, no rol estadual, de direitos presentes no rol federal, tais como a moradia, a alimentação e o transporte. ${ }^{24}$ Interessante notar que nessa hipótese de coincidência parcial tanto a norma federal pode caracterizar-se como mais protetiva quanto a norma estadual, em diferentes casos.

Ainda como um caso de coincidência parcial, registre-se que a constituição baiana assegura, em seu artigo $4^{\circ}$, VII a gratuidade do registro civil de nascimento e certidão de óbito, assemelhando-se ao artigo $5^{\circ}$ LXXVII da Constituição Federal. Mas, diferentemente desta, contempla também a gratuidade do registro de casamento, revelando-se, portanto, mais ampla a norma estadual comparativamente à norma federal. ${ }^{25}$ Note-se que neste caso, diversamente do anterior, a norma estadual é mais ampla do que a federal.

Examinados, nos limites do presente trabalho, os direitos fundamentais estaduais total e parcialmente coincidentes, convém fazer breve análise de alguns direitos fundamentais estaduais específicos, no sentido de não serem coincidentes, total ou parcialmente, com direitos fundamentais federais, o que se passa a fazer no tópico a seguir.

23 Constituição Federal: “Art. 225. Todos têm direito ao meio ambiente ecologicamente equilibrado, bem de uso comum do povo e essencial à sadia qualidade de vida, impondo-se ao Poder Público e à coletividade o dever de defendê-lo e preservá-lo para as presentes e futuras gerações." Constituição do Estado de Goiás: "Art. 127 Todos têm direito ao meio ambiente ecologicamente equilibrado, bem de uso comum do povo e essencial à sadia qualidade de vida, impondo-se ao Poder Público e à coletividade o dever de defendê-lo, recuperá-lo e preservá-lo."

24 Constituição Federal: "Art. $6^{\circ}$ São direitos sociais a educação, a saúde, a alimentação, o trabalho, a moradia, o transporte, o lazer, a segurança, a previdência social, a proteção à maternidade e à infância, a assistência aos desamparados, na forma desta Constituição." Constituição do Estado de Roraima: "Art. 50 São direitos sociais: a educação, a saúde, o trabalho, o lazer, a segurança, a previdência social, a proteção à maternidade e à infância, a assistência aos desamparados, na forma do disposto na Constituição Federal." E claro que aqui parece ocorrer a coincidência parcial do texto do dispositivo que contempla direitos fundamentais autônomos entre si.

25 Constituição Federal: "LXXVI - são gratuitos para os reconhecidamente pobres, na forma da lei: a) o registro civil de nascimento; b) a certidão de óbito;" Constituição do Estado da Bahia: “Art. $4^{\circ}$ Além dos direitos e garantias previstos na Constituição Federal ou decorrentes do regime e dos princípios que ela adota, é assegurado, pelas leis e pelos atos dos agentes públicos, o seguinte: (...) VII - serão gratuitos para os comprovadamente pobres, na forma da lei: a) os registros civis de nascimento, casamento e óbito e as respectivas certidões;”. 


\subsection{DIREITOS FUNDAMENTAIS ESTADUAIS ESPECÍFICOS OU AUTÔNOMOS}

No tratamento do tema dos direitos fundamentais estaduais, o caso mais interessante é, provavelmente, o dos direitos fundamentais específicos, ou seja, os não-coincidentes, total ou parcialmente, com os direitos fundamentais federais, mas previstos originalmente e autonomamente pelas constituições estaduais, sem constituírem cópia de disposições federais.

No presente tópico examinaremos brevemente, sem intenção de exaustão, alguns dos direitos fundamentais especificamente estaduais presentes nas constituições dos diversos estados das cinco regiões do país.

Começando pela Região Norte, da pesquisa de levantamento de dados documentais foi possível localizar direito fundamental estadual específico, sem correspondente na esfera federal, na Constituição do Estado do Acre, cujo artigo 217 estatui gratuidade no transporte coletivo estadual e municipal para pessoas com deficiência e seu acompanhante em casos de reconhecida dificuldade de locomoção.

A Constituição do Amapá, por sua vez, estabelece gratuidade da carteira de identidade, documento imprescindível ao exercício da cidadania, em seu artigo $5^{\circ}$, VI, direito público subjetivo que não encontra equivalente em nível federal, constituindo direito fundamental estadual autônomo daquela unidade da federação (e cuja ocorrência, no entanto, repete-se em diversas outras cartas estaduais).

O direito constitucional do Estado do Pará ostenta importante inovação conexa aos direitos políticos ao prever uma espécie de veto popular ou referendo revogatório sem equivalente no direito constitucional federal vigente e de rara ocorrência no direito constitucional estadual. ${ }^{26}$ A carta política daquela Unidade da Federação prevê expressamente em seu artigo $7^{\circ}$ :

\footnotetext{
todo ou em parte.

$\S 1^{\circ}$. Pode requerer plebiscito ou referendo:

I - um por cento do eleitorado estadual;

$(\ldots) "$
}

"Art. $7^{\circ}$. Através de plebiscito, o eleitorado se manifestará, especificamente, sobre fato, medida, decisão política, programa ou obra pública, e, pelo referendo, sobre emenda à Constituição, lei, projetos de emenda à Constituição e de lei, no

Além de prever consultas populares na modalidade de referendo e plebiscito, regulando-as, nota-se que aquela carta subnacional prevê hipótese sui generis de convocação

26 Até o momento foi possível identificar apenas uma disposição semelhante na Constituição do Estado de São Paulo de 1989 , cujo art. $24, \S 3^{\circ}$, itens 2 e 3 , dispõe: “A iniciativa das leis complementares e ordinárias cabe a qualquer membro ou Comissão da Assembleia Legislativa, ao Governador do Estado, ao Tribunal de Justiça, ao ProcuradorGeral de Justiça e aos cidadãos, na forma e nos casos previstos nesta Constituição. [...] $\S 3^{\circ}$ - O exercício direto da soberania popular realizar-se-á da seguinte forma: [...]2 - um por cento do eleitorado do Estado poderá requerer à Assembleia Legislativa a realização de referendo sobre lei; 3 - as questões relevantes aos destinos do Estado poderão ser submetidas a plebiscito, quando pelo menos um por cento do eleitorado o requerer ao Tribunal Regional Eleitoral, ouvida a Assembleia Legislativa; [...]" (destaques ausentes do original). Em ordens jurídicas estrangeiras o instituto é igualmente raro, ocorrendo apenas em Constituições como as da Suíça (art. 141, referendum facultativo) e Itália (art. 75, referendo abrogatório). 
popular das referidas consultas, no inciso I do $\S 1^{\circ}$ do mencionado artigo, de modo a constituir quase um veto popular ou referendo ab-rogatório quase sem equivalente no direito brasileiro contemporâneo. A única ressalva a ser feita, que esvazia em parte o instituto, é que o $\S 2^{\circ}$ do mesmo dispositivo condiciona a realização da consulta a autorização do legislativo estadual - o que descaracteriza o veto popular propriamente dito.

A carta política do Estado do Amazonas, em seu artigo 186, garante à mulher a livre opção pela maternidade e a interrupção da gravidez, nas hipóteses legais, com direito a atendimento clínico, judicial e psicológico necessários.

A Constituição do Estado de Rondônia, em seu artigo 17, estabelece direito fundamental autônomo em favor das pessoas com deficiência, ao prever direito ao transporte público gratuito para as mesmas. A Constituição do Estado de Tocantins, no artigo 134-A, incluído pela Emenda Constitucional n. 29, de 28.06.2016, estabelece a garantia de ensino superior gratuito por meio da manutenção de universidade estadual pública.

Também nas Constituições dos Estados do Nordeste constatou-se a existência de direitos fundamentais estaduais autônomos ou específicos. A Constituição do Estado do Ceará prevê interessante hipótese de imunidade tributária estadual em seu artigo 201, parágrafo único, cujo teor requer transcrição literal:

“Art. 201. Não incidirá imposto, conforme a lei dispuser, sobre todo e qualquer produto agrícola pertencente à cesta básica, produzido por pequenos e microprodutores rurais que utilizam apenas a mão-de-obra familiar, vendido diretamente aos consumidores finais.

Parágrafo único. A não incidência abrange produtos oriundos de associações e cooperativas de produção e de produtores, cujos quadros sociais sejam compostos exclusivamente por pequenos e microprodutores e trabalhadores rurais sem terra."

Trata-se de relevante norma constitucional claramente estabelecedora de direito fundamental e conexa tanto a finalidades constitucionais de proteção da agricultura familiar quanto ao mínimo vital e mínimo existencial. De qualquer modo, deve-se registrar que o dispositivo foi objeto da ADI n. 429-8, tendo sido declarado inconstitucional pelo STF em 2014.

A constituição da Bahia, por sua vez, assegura a todos o direito dos serviços de água, esgoto e energia elétrica, vedando a suspensão de tais serviços para aqueles que sejam incapazes de pagar pelos referidos serviços públicos essenciais:

“Art. $4^{\circ}$ Além dos direitos e garantias previstos na Constituição Federal ou decorrentes do regime e dos princípios que ela adota, é assegurado, pelas leis e pelos atos dos agentes públicos, o seguinte:

$(\ldots)$

VI - comprovada a absoluta incapacidade de pagamento, definida em lei, ninguém poderá ser privado dos serviços públicos de água, esgoto e energia elétrica;”.

A norma evidentemente é autônoma, não reproduzindo nenhum preceito federal, 
inova de maneira relevante o sistema de direitos fundamentais, e revela-se, assim como a norma cearense recém examinada, um mecanismo relevante de proteção do mínimo vital e existencial.

Disposição semelhante, mas não idêntica, encontra-se no Estado do Sergipe, que assegura constitucionalmente os serviços essenciais à saúde, higiene ou educação independentemente da disposição de recursos financeiros:

\footnotetext{
'Art. $3^{\circ}$. O Estado assegura por suas leis e pelos atos dos seus agentes, além dos direitos e garantias individuais previstos na Constituição Federal e decorrentes do regime e dos princípios que ela adota, ainda os seguintes:

I - ninguém será prejudicado no exercício de direito, nem privado de serviço essencial à saúde, à higiene e à educação, por não dispor de recursos financeiros;”"
}

A constituição piauiense, por sua vez, prevê interessante direito fundamental estadual autônomo ao estatuir isonomia de direitos entre a mãe biológica e a adotante, conforme disposto em seu artigo 252, segundo o qual "são assegurados às mães adotivas os mesmos direitos garantidos às mães legítimas, inclusive o de licença maternidade, na forma da lei”. ${ }^{27}$

A Constituição do Estado do Alagoas prevê a obrigatoriedade da oferta de educação religiosa nas escolas públicas estaduais e municipais em seu artigo 201, com matrícula facultativa e caráter ecumênico, entre outros aspectos.

O Estado do Maranhão estabelece no art. $217 \S$ único de sua constituição direito fundamental autônomo consistente na gratuidade não apenas da educação, mas também do material escolar e alimentação dos educandos, além de prever expressamente a vedação da cobrança de taxas nos estabelecimentos públicos de ensino.

Na Região Centro-Oeste, o Direito Constitucional do Estado do Mato Grosso apresenta importante previsão de direito fundamental relativa à tutela das informações pessoais, à privacidade e à intimidade, entre outros, em seu art. 10, XIII, que traduz disposição que aparece em diversas constituições estaduais, cujo teor é o seguinte:

\begin{abstract}
"XIII - são vedados o registro ou a exigência de informações, para inserção em bancos de dados estaduais ou municipais, públicos ou privados, referentes a convicções políticas, filosóficas ou religiosas, à filiação partidária ou sindical e outras concernentes à vida privada e à intimidade pessoal, salvo quando se tratar de processamento estatístico e não individualizado;"
\end{abstract}

A norma, sem equivalente na Constituição Federal, evidentemente resguarda diversos âmbitos dos direitos pessoais (SARLET, MARINONI, MITIDIERO, 2018), do livre desenvolvimento da personalidade, da consciência e da crença individuais, e revela-se mecanismo importante para evitar tratamentos discriminatórios ou privilegiados, perseguições por motivos sectários, entre outros.

27 Note-se que o art. $227 \S 6^{\circ}$ da Constituição federal prevê igualdade de direitos entre filhos oriundos do casamento ou não e de adoção, não dispondo sobre as mães, e que o texto da Constituição Federal é silente sobre licença maternidade da adotante. 
No que tange ao direito fundamental à saúde, encontra-se importante norma estabelecedora de direito fundamental na Constituição do Estado de Mato Grosso do Sul, artigo $173 \S 1^{\circ}$ :

"Art. 173. A saúde é direito de todos e dever do Estado, garantido através de políticas sociais e econômicas que visem à redução do risco de doenças e de outros agravos e ao acesso universal e igualitário às ações e serviços para sua promoção, proteção e recuperação.

$\S 1^{\circ}$ Assegura-se aos portadores de hanseníase; câncer; doença renal crônica; síndrome de imunodeficiência adquirida; tuberculose e outras moléstias, desde que comprovadamente carentes e pelo período de duração do tratamento que, embora contínuo, dispense a internação hospitalar, o direito ao transporte público gratuito, garantido pelo Estado e Município, conforme seja intermunicipal ou municipal o seu deslocamento."

Tal dispositivo foi acrescentado àquela constituição subnacional pela Emenda Constitucional n. 14, de 29.06.1999 e declarado parcialmente inconstitucional pelo STF no âmbito do julgado do RE n. 1148326, julgado em 2019.

Por fim, ainda na Região Centro-Oeste, encontra-se direito fundamental estadual autônomo na Lei Orgânica do Distrito Federal, a qual, em seu art. 123 e $§$ único, assegura o direito de presidiárias e seus filhos a creche em local anexo ao estabelecimento prisional, em tempo integral, para os filhos de 0 a 6 anos, bem como o direito à amamentação até completar no mínimo 12 meses, entre outros direitos, como assistência pré-natal.

Na Região Sudeste também foi possível identificar direitos fundamentais estaduais autônomos. O destaque recai sobre disposição da Constituição do Estado do Rio de Janeiro (artigo $22 \S 3^{\circ}$ ), referente à inviolabilidade de sedes de entidades associativas, cuja transcrição segue:

"Art. 22 - São invioláveis a intimidade, a vida privada, a honra e a imagem das pessoas, assegurado o direito de resposta proporcional ao agravo, além da indenização pelo dano material ou moral decorrente da violação de qualquer daqueles direitos.

(...)

$\S 3^{\circ}$ - São invioláveis as sedes de entidades associativas, ressalvados os casos previstos em lei."

A norma reveste-se de autonomia e fundamentalidade evidentes, contemplando ampliação expressa importante da área de proteção da liberdade de associação constitucionalmente estabelecida. Ademais, o $\S 2^{\circ}$ da disposição prevê que "não serão admitidas a pregação da intolerância religiosa ou a difusão de preconceitos de qualquer espécie.”

A Região Sul contempla igualmente direitos fundamentais estaduais específicos. A ordem constitucional estadual catarinense, por exemplo, após assegurar os direitos e garantias individuais e coletivos previstos na Constituição Federal em seu art. $4^{\circ}$, caput, estatui no inciso II, alínea "d" do mesmo dispositivo, que "são gratuitos, para os reconhecidamente pobres, na forma 
da lei: (...) d) o registro e a certidão de adoção de menor."

Esse direito fundamental novamente não encontra equivalente nas normas constitucionais federais, evidenciando uma vez mais a autonomia do Direito Constitucional estadual relativamente ao federal.

Por fim, registre-se que o artigo 25 da Constituição do Rio Grande do Sul estatui o direito de uma representação eletiva dos empregados na direção de empresas públicas e autarquias estaduais, e que a Constituição do Estado do Paraná contempla em seu rol de direitos fundamentais norma específica, embora expressão do direito fundamental à saúde, ao assegurar políticas públicas preventivas e terapêuticas para câncer e diabetes (art. 170, I e II), previsão esta fruto da redação conferida ao dispositivo pela Emenda Constitucional n. 25 de 19.12.2009. ${ }^{28}$

Como se percebe do breve panorama aqui traçado, sem pretensão de exaurir o vasto tema dos direitos fundamentais estaduais, os constituintes estaduais não se limitaram a repetir aqueles direitos previstos na Constituição Federal, mas inovam com frequência, com maior ou menor criatividade, fazendo existir uma interessante dualidade de direitos fundamentais na complexa ordem jurídica brasileira (FERREIRA, 1964).

\section{CONCLUSÕES}

A pesquisa realizada até o momento permitiu constatar aspectos importantes relativos às constituições estaduais e à Lei Orgânica do Distrito Federal quanto a diversos aspectos referentes à sua vigência, extensão, estrutura, estabilidade e conteúdo, entre outros aspectos.

Quanto ao conteúdo, percebe-se que apesar de as cartas constitucionais estaduais possuírem, em boa medida, caráter predominantemente orgânico e procedimental, contemplam importantes disposições de fundo, especialmente na parte dogmática ou limitadora, ou seja, em matéria de direitos fundamentais.

Tais disposições são contempladas em títulos próprios em quase dois terços das constituições subnacionais, e, em pouco mais de um terço delas, em títulos destinados a temáticas relacionadas à ordem econômica e social e temas conexos, como o meio ambiente.

$\mathrm{O}$ estudo permitiu demonstrar que, a despeito do caráter centralizador da federação brasileira, o pluralismo constitucional brasileiro contempla certo grau de criatividade no constitucionalismo estadual, que se manifesta em diversos aspectos e que é digno de atenção por sua importância teórica e prática.

Permitiu demonstrar ainda que a concepção preponderante na doutrina nacional acerca dos direitos fundamentais é reducionista, por focar-se apenas na ordem constitucional federal, desconsiderando frequentemente a existência de direitos fundamentais estaduais, sendo

\footnotetext{
28 Constituição do Estado do Paraná: “Art. 170. O Estado e os Municípios dotarão os serviços de saúde de meios adequados ao atendimento à saúde da família, da mulher, da criança, do adolescente, do jovem e do idoso objetivando também, quando da instituição do plano plurianual, garantir as seguintes políticas sociais regulamentadas em Lei Complementar: I - exames periódicos gratuitos para os domiciliados no Estado, objetivando prevenção do câncer e do diabetes, garantindo aos portadores o fornecimento de medicamentos e insumos destinados ao tratamento e controle destas doenças; II - exames semestrais aos alunos da rede pública de ensino objetivando prevenção do câncer e do diabetes, além de campanhas educativa."
} 
que a coexistência de tais direitos acarreta questões de significativo interesse (SAMPAIO, 2019).

Da análise dos direitos fundamentais estaduais em espécie em comparação entre si e para com a Constituição Federal foi possível constatar situações de coincidência total ou parcial de direitos fundamentais federais e estaduais, o que engendra questionamentos sobre a caracterização de conflito, colisão ou concorrência de direitos fundamentais de diversos níveis de positivação e dos critérios de solução de tais casos.

Foi possível demonstrar, ainda, a existência de cláusulas de abertura e/ou reenvio estaduais que, ao incorporarem direitos fundamentais federais ou fazerem remissão a normas da Constituição Federal ou mesmo de direito supranacional tornam o sistema jurídico ainda mais complexo, pela interação dos vários níveis de proteção (constitucionalismo multinível).

Viu-se, ainda, que as constituições estaduais inovam também, em termos de tutela de direitos fundamentais, ao estabelecer controle primário para o combate da omissão inconstitucional administrativa inviabilizadora do exercício de direitos fundamentais, o que se revela igualmente instigante.

Por fim, foi possível constatar e demonstrar a existência de direitos fundamentais estaduais específicos ou autônomos, isto é, que não constituem cópia de direitos fundamentais federais, mas que consistem em direitos públicos subjetivos de nível constitucional independentes daqueles.

\section{REFERÊNCIAS}

ACRE. Constituição do Estado, de 03 de outubro de 1989. Disponível em: $<$ http://www.al.ac. leg.br/leis/?page_id=12438>. Acesso em: 19.03.2019.

ALAGOAS. Constituição do Estado, de 05 de outubro de 1989. Disponível em: < http:// www.procuradoria.al.gov.br/legislacao/constituicao-do-estado-de-alagoas/Livro\%20da\%20 Constituicao\%20do\%20Estado\%20de\%20Alagoas\%20sem\%20Capa.pdf/view>. Acesso em: 19.03.2019.

AMAPÁ. Constituição do Estado, de 20 de dezembro de 1991. Disponível em: < https://sead. portal.ap.gov.br/constituicao_estadual>. Acesso em: 19.03.2019.

AMAZONAS. Constituição do Estado, de 05 de outubro de 1989.Disponível em: $<$ http://www. ale.am.gov.br/wp-content/uploads/2018/12/CONSTITUIcaO-DO-ESTADO-DO-AMAZONASDEZ-2018.pdf>. Acesso em: 19.03.2019.

BAHIA. Constituição do Estado, de 05 de outubro de 1989. Disponível em: <http://www.al.ba. gov.br/atividade-legislativa/legislacao/constituicao-estadual>. Acesso em: 19.03.2019.

BONAVIDES, Paulo. Ciência Política. 16 ed. São Paulo: Malheiros, 2009.

BRASIL. Constituição da República Federativa do Brasil, de 05 de outubro de 1988. Disponível em: $<$ http://www.planalto.gov.br/ccivil_03/constituicao/constituicao.htm $>$. Acesso em: 19.03.2019. 
CANOTILHO, José Joaquim Gomes. Direito Constitucional \& Teoria da Constituição. 7 ed. Coimbra: Almedina, 2003.

CEARÁ. Constituição do Estado, de 05 de outubro de 1989. Disponível em: <https://www. ceara.gov.br/wp-content/uploads/2017/03/Const-2015-260-200-Atualizada-emenda-86-4.pdf>. Acesso em: 19.03.2019.

COUTO, Cláudio Gonçalves; ABSHER-BELLON, Gabriel Luan. Imitação ou coerção? Constituições estaduais e centralização federativa no Brasil. Revista de Administração Pública, v. 52, n. 2, mar./abr. 2018, pp. 321-344.

DIMOULIS, Dimitri; MARTINS, Leonardo. Teoria Geral dos Direitos Fundamentais. 2 ed. rev., atual. e ampl. São Paulo: RT 2009.

DISTRITO FEDERAL. Lei Orgânica do Distrito Federal, de 08 de junho de 1993. Disponível em: <https://www.cl.df.gov.br/pesquisa-de-leis-e-proposicoes $>$. Acesso em: 19.03.2019.

ESPIRITO SANTO. Constituição do Estado, de 05 de outubro de 1989. Disponível em:< http:// www.al.es.gov.br/appdata/anexos_internet/downloads/c_est.pdf $>$. Acesso em: 19.03.2019.

FERREIRA, Luiz Pinto. As Constituições dos Estados no regime federativo. Revista de Informação Legislativa, v. 01, n. 02, jun.1964, pp. 18-58.

GOIÁS. Constituição do Estado, de 05 de outubro de 1989. Disponível em:< http://www. gabinetecivil.goias.gov.br/constituicoes/constituicao_1988.htm>. Acesso em: 19.03.2019.

TOMIO, Fabrício Ricardo de Limas; ROBL FILHO, Ilton Norberto; KANAYAMA, Rodrigo. Constitucionalismo estadual e controle abstrato e concentrado de constitucionalidade nos Tribunais de Justiça: efeitos das Ações Diretas de Inconstitucionalidade (ADI) estaduais na federação brasileira. Revista de Direito Brasileira, ano 5, v. 12, 2015, pp. 88-110.

LEONCY, Leo Ferreira. Controle de Constitucionalidade Estadual: As normas de observância obrigatória e a defesa abstrata da Constituição do Estado-membro. São Paulo: Saraiva, 2007.

MADDEX, Robert L. State Constitutions of the United States. Whashington: Congressional Quarterly, 1998.

MARANHÃO. Constituição do Estado, de 05 de outubro de 1989. Disponível em: <http:// legislacao.al.ma.gov.br/ged/cestadual.html>. Acesso em: 19.03.2019.

MATO GROSSO. Constituição do Estado, de 05 de outubro de 1989. Disponível em: $<$ http:// www.al.mt.gov.br/arquivos/parlamento/ssl/constituicao-estadual.pdf $>$. Acesso em: 19.03.2019.

MATO GROSSO DO SUL. Constituição do Estado, de 05 de outubro

de 1989. Disponível em: <http://aacpdappls.net.ms.gov.br/appls/

legislacao/secoge/govato.nsf/0a67c456bc566b8a04257e590063fl fd/

dfde24a4767ddcbf04257e4b006c0233? OpenDocument>. Acesso em: 19.03.2019. 
MINAS GERAIS. Constituição do Estado, de 21 de setembro de 1989. Disponível em:< https://www.almg.gov.br/consulte/legislacao/completa/completa-nova-min. html?tipo=Con\&num=1989\&ano=1989>. Acesso em: 19.03.2019.

PARÁ. Constituição do Estado, de 05 de outubro de 1989. Disponível em: <http://www.cee. pa.gov.br/sites/default/files/Constituicao_do_Para_-_ate_a_EC_43.pdf > . Acesso em: 19.03.2019. PARAÍBA. Constituição do Estado, de 05 de outubro de 1989. Disponível em: <http://www. al.pb.leg.br/wp-content/uploads/2017/02/Constitui\%C3\%A7\%C3\%A3o-Estadual-Atualizadaat\%C3\%A9-a-Emenda-40-de-2015.pdf>. Acesso em: 19.03.2019.

PARANÁ. Constituição do Estado, de 05 de outubro de 1989. Disponível em: <http://www. alep.pr.gov.br/legislacao/constituicao_estadual>. Acesso em: 19.03.2019.

PERNAMBUCO. Constituição do Estado, de 05 de outubro de 1989. Disponível em: $<$ http:// legis.alepe.pe.gov.br/texto.aspx?id=4937>. Acesso em: 19.03.2019.

PIAUÍ. Constituição do Estado, de 05 de outubro de 1989. Disponível em: < http://legislacao. pi.gov.br/legislacao/default/ato/14853>. Acesso em: 19.03.2019.

POLLOCK, Stewart G. State Constitutions as Separate Sources of Fundamental Rights. Rutgers Law Review, v. 35, n. 4, 1983, pp. 707-722.

RIO DE JANEIRO. Constituição do Estado, de05 de outubro de 1989. Disponível em: <http:// alerjln1.alerj.rj.gov.br/constest.nsf/PageConsEst?OpenPage>. Acesso em: 19.03.2019.

RIO GRANDE DO NORTE. Constituição do Estado, de 03 de outubro de 1989. Disponível em: <http://www.al.rn.gov.br/portal/_ups/ legislacao/2015/06/22/01eb1a7dc129b162fb8a658ef428fd6e.pdf>. Acesso em: 19.03.2019.

RIO GRANDE DO SUL. Constituição do Estado, de 03 de outubro de 1989. Disponível em:< http://www2.al.rs.gov.br/dal/LinkClick. aspx?fileticket=WQdIfqNoXO4\%3d\&tabid=3683\&mid=5359> . Acesso em: 19.03.2019.

RONDÔNIA. Constituição do Estado, de 28 de setembro de 1989. Disponível em: < http:// www.al.ro.leg.br/institucional/constituicao-do-estado-de-rondonia/ce1989_ec132.pdf/view>. Acesso em: 19.03.2019.

RORAIMA. Constituição do Estado, de 31 de dezembro de 1991. Disponível em:< https:// www.tjrr.jus.br/legislacao/index.php/constituicao-estadual>. Acesso em: 19.03.2019.

ROSARIO RODRÍGUEZ, Marcos Del. Protección, reconocimiento y eficacia de los derechos fundamentales en las constituciones locales. Revista Iberoamericana de Derecho Procesal Constitucional, n. 11, jan./jun. 2009, pp. 217-234.

SANTA CATARINA. Constituição do Estado, de 05 de outubro de 1989. Disponível em: $<$ http://leis.alesc.sc.gov.br/html/constituicao_estadual_1989.html >. Acesso em: 19.03.2019.

SARLET, Ingo W. Eficácia dos Direitos Fundamentais: Uma Teoria Geral dos Direitos Fundamentais na Perspectiva Constitucional. 11 ed. rev. e atual. Porto Alegre: Livraria do 
Advogado Editora, 2012.

SARLET, Ingo Wolfgang; MARINONI, Luiz Guilherme; MITIDIERO, Daniel. Curso de Direito Constitucional. 7 ed. rev., atual. e ampl. São Paulo: Saraiva, 2018.

SAMPAIO, José Adércio Leite. As Constituições subnacionais e direitos fundamentais nas federações. Revista Direito da Cidade, v. 11, n. 1, 2019, pp. 183-215.

SÃO PAULO (Estado). Constituição do Estado, de 05 de outubro de 1989. Disponível em: $<$ https://www.al.sp.gov.br/repositorio/legislacao/constituicao/1989/compilacaoconstituicao-0-05.10.1989.html>. Acesso em: 19.03.2019.

SERGIPE. Constituição do Estado, de 05 de outubro de 1989. Disponível em: <https://al.se.leg. br/arq_transparencia/arq_constituicao/constituicao_estadual_2017.pdf $>$. Acesso em: 19.03.2019.

SGARBOSSA, Luís Fernando. Direitos Fundamentais Extravagantes: Interpretação Jusfundamental "Pro Homine". Porto Alegre: Sergio Antonio Fabris Editor, 2008a.

SGARBOSSA, Luís Fernando. Elementos de Direito Comparado: Ciência, Política Legislativa, Integração e Prática Judiciária. Porto Alegre: Sergio Antonio Fabris Editor, 2008b.

SGARBOSSA, Luís Fernando. Estado federal e pluralismo constitucional: Direito Constitucional estadual e experimentalismo democrático. In: BOLONHA, Carlos; LIZIERO, Leonam;

SEPULVEDA, Antonio. Federalismo: Desafios Contemporâneos. Porto Alegre: Editora Fi, 2019, pp. 53-72.

SILVA, José Afonso da. Curso de Direito Constitucional Positivo. 34 ed. rev. e ampl. São Paulo: Malheiros, 2011.

SILVA, Virgílio Afonso da. Ulisses, as sereias e o poder constituinte derivado: sobre a inconstitucionalidade da dupla revisão e da alteração do quorum de $3 / 5$ para a aprovação de emendas constitucionais. Revista de Direito Administrativo, n. 226, 2001, pp. 11-32.

TOCANTINS. Constituição do Estado, de 05 de outubro de 1989. Disponível em: $<$ http://www. al.to.leg.br/arquivos/documento_42780.PDF\#dados>. Acesso em: 19.03.2019.

ZACKIN, Emily. Looking for Rights in All the Wrong Places: Why State Constitutions Contain America's Positive Rights. Princeton: Princeton University Press, 2013.

Recebido em: 23/04/2019.

Aprovado em: 30/06/2019. 